\title{
Studies on Protein Digestion in Ruminants
}

\section{Effect of Carbohydrates and Antibiotics on the Ammonia Concentration}

\author{
Sadao Hoshino \\ (Faculty of Agriculture, Mie University) \\ (Received for publication on February 16, 1965)
}

In previous paper ${ }^{91}$, it was shown that addition of glucose to casein diet markedly decreased the ammonia concentration in rumen of sheep. The experiments described here were undertaken to find whether the same results would be obtained by addition of the other carbohydrates and antibiotics in vitro.

\section{Materials and Methods}

An adult female Corriedale sheep, weighing $75 \mathrm{~kg}$ was used. The animal was fitted a permanent rumen fistula.

The daily ration was fed to the animal at $9: 00 \mathrm{am}$ and 5:00 pm, and consisted of $2 \mathrm{~kg}$ green soybean hay and $300 \mathrm{~g}$ concentrate (rice bran 2: wheat bran 1), containing $3 \%$ of calcium carbonate and $1 \%$ of salt. Water was supplied ad libitum.

Rumen samples were taken immediately prior to morning feeding through the fistula. The samples were strained through four layers of gauze and immediately added to the fermentation flasks $(50 \mathrm{~m} l$ conical flask).

The composition of standard flasks is shown in Table 1. Casein and carbohydrates were

Table 1. Composition of fermentation flasks

\begin{tabular}{|c|c|c|c|c|}
\hline & & Blank & Control & Test \\
\hline \multirow{2}{*}{\multicolumn{2}{|c|}{$\begin{array}{l}\text { Strained whole rumen liquor } \\
\text { Casein solution }(1 \%)\end{array}$}} & $5 \mathrm{~m} l$ & $5 \mathrm{~m} l$ & $5 \mathrm{ml}$ \\
\hline & & - & 511 & \\
\hline \multirow{6}{*}{ Carbohydrate } & $0.5 \mathrm{M}$ solution $\mathrm{a}$ & - & - & \\
\hline & $0.25 \mathrm{M} \quad \prime \prime \quad \mathrm{b}$ & - & - & 511 \\
\hline & $0.15 \mathrm{M} \quad \| \prime \quad \mathrm{c}$ & - & - & \\
\hline & $10 \% \quad \prime \prime d$ & - & - & \\
\hline & $" 1 \mathrm{e}$ & - & - & $5 \prime \prime$ \\
\hline & add directly & - & - & $0.25 \mathrm{~g}$ \\
\hline \multirow{4}{*}{ Antibiotic } & $200 \sim 6,000 \mathrm{IU} / \mathrm{m} l \mathrm{~h}$ & - & - & $5 \mathrm{~m} l$ \\
\hline & $20 \sim 40 \mathrm{mg} / \mathrm{ml}$ & - & 一 & $5 \prime \prime$ \\
\hline & $0.6 \sim 2.5 \mathrm{mg} / \mathrm{m} l i j$ & - & - & $5 \prime \prime$ \\
\hline & add directly $\mathrm{k}$ & - & - & $10 \sim 300 \mathrm{mg}$ \\
\hline Phosphate bul & $\mathrm{er}(\mathrm{M} / 15, \mathrm{pH} 6.80)$ & $20^{\prime \prime}$ & $15^{\prime \prime}$ & $10 \sim 15 \mathrm{~m} l$ \\
\hline
\end{tabular}

a): xylose, glucose, fructose, galactose, mannose, sucrose, lactose, and maltose.

b) : cellobiose. c): raffinose. d): dextrin. e): starch and inulin. f): xylan and cellulose.

h): penicillin G. i) : streptomycin. j): tetracycline. k): kanamycin. 
dissolved in $\mathrm{M} / 15$ phosphate buffer at $\mathrm{pH} 6.80$ unless otherwise provided. Xylan and cellulose were added directly to the medium. Penicillin (ptassium penicillin G, by Takeda Chemical Industries Ltd.) was dissolved in water. Streptomycin (dihydrostreptomycini sulfas DAIICHI, by Daiichi Seiyaku Co., Ltd.) and tetracycline (chlortetracycline, by Meiji Seika Co., Ltd.) were also dissolved in water and neutralized with NaOH. Kanamycin (kanamycin sulfate, by Takeda Chemical Industries Ltd.) was added directly to the medium. The apparent endogenous ammonia production was determined by the analysis of blank flask. The apparent ammonia production in the presence of casein was measured by control flask. The test flask was consisted of strained whole rumen liquor, casein, carbohydrate or antibiotic and made the same total volume $(25 \mathrm{ml})$ as control and blank flask with phosphate buffer. The effect of added carbohydrates and antibiotics was calculated by next equation:

Decrease $(\%)=100-(T-B) /(C-B) \times 100$

where $\mathrm{B}$ is ammonia- $\mathrm{N} \mu \mathrm{g} / \mathrm{m} l$ of reaction mixture in blank flask, $\mathrm{C}$ is that in control flask and $T$ is that in test flask.

After air phase of the flasks was replaced by carbon dioxide, the flasks were closed tightly by rubber stoppers and incubated in waterbath at $39^{\circ} \mathrm{C}$ for two hours. Then, the flasks were placed in crushed ice and the reaction mixture were submitted to nitrogen analysis. The nitrogen fractions were analysed by the procedures employed by KANDATSU and TAKAHASHI ${ }^{10)}$ : ammonia nitrogen; the method of VAN SLYKE-CULLEN ${ }^{23}$. Microbial nitrogen; $10 \mathrm{~m} l$ of reaction mixture was centrifuged for 30 minutes at 12,000 r.p.m. $(10,000 \mathrm{~g})$. The sediment was washed twice with water and the nitrogen was analysed by Kjeldahl method. Protein (casein) nitrogen; $5 \mathrm{~m} l$ of $20 \%$ trichloracetic acid solution was added to $5 \mathrm{~m} l$ of the above supernatant and was allowed to stand for overnight in refrigerator. The sediment was collected and analysed by Kjeldahl method. Soluble nitrogen; the above deproteinized supernatant was analysed by Kjeldahl method. Amino nitrogen; the deproteinized supernathant was neutralized with $\mathrm{NaOH}$ and analysed by VAN-SLYKE method ${ }^{11}$.

The $\mathrm{pH}$ values were determined by use of a glass electrode $\mathrm{pH}$ meter (Model, $\mathrm{M}-4$, by Hitachi-Horiba).

Statistical procedures were applied as suggested by SNEDECoR ${ }^{23}$.

\section{Results}

The effect of carbohydrates and antibiotics on the ammonia- $\mathrm{N}$ concentration is shown in Table 2. As shown in last column in Table 2, ammonia-N concentration was markedly decreased $(74 \sim 141 \%)$ by addition of xylose, glucose, fructose, galactose, sucrose, maltose, lactose, cellobiose and raffinose respectively. Decrease $(34 \sim 55 \%)$ in ammonia-N concentration was also observed by addition of mannose, dextrin, starch, inulin and xylan respectively, but the effect was rather small than the above group. Addition of cellulose, however, gave no effect within 2 hours.

Addition of $4 \mathrm{mg} / \mathrm{m} l$ of streptomycin or $0.5 \mathrm{mg} / \mathrm{ml}$ of tetracycline depressed the apparent ammonia production very much. However, there was a little effect at the other concentration $(8 \mathrm{mg} / \mathrm{m} l$ and $0.12 \mathrm{mg} / \mathrm{ml}$ ) of these antibiotics (Table 2). Penicillin had no effect even in high unit. Addition of kanamycin showed increase in ammonia- $N$ concentration.

The changes of nitrogen distribution and $\mathrm{pH}$ caused by addition of $0.1 \mathrm{M}$ fructose were measured and results are given in Table 3 and 4. As shown in Table 3, microbial nitrogen 


\section{Hoshino}

Table 2. Effect of carbohydrates and antibiotics on ammonia-N concentration

\begin{tabular}{|c|c|c|c|c|c|c|c|c|}
\hline & Blank & (B) & Control & (C) & Test & $(\mathrm{T})$ & \multirow{3}{*}{\multicolumn{2}{|c|}{$\frac{\left\{\begin{array}{c}\text { Derease (\%) } \\
\left(100-\frac{\mathrm{T}-\mathrm{B}}{\mathrm{C}-\mathrm{B}} \times 100\right.\end{array}\right.}{80 \pm 11 \mathrm{~b}}$}} \\
\hline & \multicolumn{6}{|c|}{$\left(\mathrm{NH}_{8}-\mathrm{N} / \mathrm{g} / \mathrm{m} l\right.$ of reaction mixture) } & & \\
\hline Xylose $\quad(0.1 \mathrm{M})$ a & $52 \pm$ & $4 \mathrm{~b}$ & $70 \pm$ & $5 \mathrm{~b}$ & $56 \pm$ & $=2^{b}$ & & \\
\hline Glucose $(" \prime)$ & 33 & 7 & 46 & 9 & 35 & 10 & 82 & 9 \\
\hline Fructose $(" \prime)$ & 51 & 6 & 75 & 10 & 51 & 6 & 101 & 4 \\
\hline Galactose ( $1 /)$ & 37 & 8 & 57 & 4 & 43 & 2 & 74 & 15 \\
\hline Mannose $(" /)$ & 46 & 5 & 82 & 1 & 71 & 3 & 34 & 7 \\
\hline Sucrose $(\|)$ & 54 & 4 & 73 & 2 & 46 & 2 & 141 & 8 \\
\hline Lactose (") & 47 & 8 & 65 & 11 & 50 & 7 & 77 & 18 \\
\hline Maltose (") & 35 & 3 & 55 & 3 & 36 & 3 & 93 & 7 \\
\hline Raffinose $(0.03 \mathrm{M})$ & 44 & 4 & 62 & 7 & 47 & 4 & 84 & 5 \\
\hline Dextrin $(2 \%)$ & 34 & 4 & 55 & 8 & 45 & 1 & 48 & 6 \\
\hline Starch $\quad(1 \%)$ & 49 & 5 & 75 & 2 & 64 & 5 & 42 & 10 \\
\hline Xylan $(1 /)$ & 40 & 5 & 51 & 8 & 43 & 6 & 55 & 20 \\
\hline Inulin $(11)$ & 36 & 7 & 57 & 8 & 48 & 7 & 44 & 1 \\
\hline Cellobiose $(0.05 \mathrm{M})$ & 34 & 2 & 54 & 1 & 33 & 5 & 104 & 20 \\
\hline Cellulose $(1 \%)$ & 60 & 7 & 78 & 9 & 76 & 8 & 11 & 2 \\
\hline Penicillin G (40 IU $/ \mathrm{m} l)$ & 40 & & 48 & & 47 & & 12 & \\
\hline$\prime \prime \quad(400 \mathrm{IU} / \mathrm{m} l)$ & 38 & & 48 & & 44 & & 40 & c \\
\hline$" \prime \quad(1,200 \mathrm{IU} / \mathrm{m} l)$ & 80 & & 121 & & 117 & & 10 & $\mathrm{c}$ \\
\hline Streptomycin $(4 \mathrm{mg} / \mathrm{m} l)$ & 99 & & 111 & & 88 & & 192 & $\mathrm{c}$ \\
\hline$\| \quad(8 \mathrm{mg} / \mathrm{ml})$ & 92 & 2 & 125 & 9 & 118 & 6 & 22 & 4 \\
\hline Kanamycin $(0.4 \mathrm{mg} / \mathrm{ml})$ & 115 & & 141 & & 136 & & 19 & c \\
\hline$\prime \quad(12 \mathrm{mg} / \mathrm{m} l)$ & 59 & 4 & 82 & 1 & 99 & 6 & -85 & 29 \\
\hline Tetracycline $(0.12 \mathrm{mg} / \mathrm{m} l)$ & 79 & & 100 & & 96 & & 19 & c \\
\hline$\prime \prime \quad(0.50 \mathrm{mg} / \mathrm{m} l)$ & 81 & 7 & 122 & 11 & 92 & 7 & 84 & 11 \\
\hline
\end{tabular}

a): final concentration, b); standard frror. c : single determination.

considerably increased by addition of fructose than control and the difference from it was significant $(\mathrm{p}<.01)$. The blank flask showed decrease in microbial nitrogen. Ammonia- $\mathrm{N}$ concentration of the test flask showed same level as blank and difference from control was significant $(\mathrm{p}<.01)$. After two hours incubation the $\mathrm{pH}$ dropped by addition of fructose and difference from control was significant $(p<.01)$. Protein and soluble nitrogen decreased by addition of fructose, however, the differences from control being not significant. Amino nitrogen gave high concentration by addition of fructose than control, but the difference from it was not significant.

As shown in Table 3 and 4 , when fructose was added to medium, the significant drop in $\mathrm{pH}$ values was accompanied with significant decrease in ammonia concentration. So, the relationship between $\mathrm{pH}$ and ammonia concentration was investigated. Result is presented in Fig. 1. From this figure, the optimum $\mathrm{pH}$ for apparent ammonia production was around 7.0 and below $\mathrm{pH} 6.0$ or above $\mathrm{pH} 8.0$, the ammonia-N concentration was rather low. However, apparent ammonia production was observed in relatively wide $\mathrm{pH}$ ranges ( $\mathrm{pH} 5.25 \sim 8.0$ ) employed. 
Protein Digestion in Ruminants $\mathrm{V}$

Table 3. Effect of fructose on nitrogen distribution and $\mathrm{pH}$

\begin{tabular}{|c|c|c|c|c|c|c|c|}
\hline \multirow{3}{*}{ Microbial-N } & \multicolumn{2}{|c|}{ Blank (B) } & \multicolumn{2}{|c|}{ Control (C) } & \multicolumn{2}{|c|}{ Test (T) } & \multirow{6}{*}{$\begin{array}{l}\mathrm{B}-\mathrm{C}, \mathrm{T}^{* *} \\
\mathrm{C}-\mathrm{T}^{* *}\end{array}$} \\
\hline & \multicolumn{6}{|c|}{$(\mathrm{N} \mu \mathrm{g} / \mathrm{m} l$ of reaction mixture $)$} & \\
\hline & \multirow{2}{*}{\multicolumn{2}{|c|}{$346 \pm 41 b$}} & \multirow{2}{*}{\multicolumn{2}{|c|}{$346 \pm 39 \mathrm{~b}$}} & \multirow{2}{*}{\multicolumn{2}{|c|}{$365 \pm 46 \mathrm{~b}$}} & \\
\hline Before incubation & & & & & & & \\
\hline After incubation & 336 & 43 & 359 & 43 & 399 & 45 & \\
\hline Increase & -10 & 6 & 13 & 4 & 34 & 4 & \\
\hline \multicolumn{8}{|l|}{ Protein-N } \\
\hline Before incubation & - & & 357 & 12 & 330 & 28 & \\
\hline After incubation & - & & 136 & 23 & 133 & 32 & \\
\hline Increase & - & & -221 & 25 & -197 & & \\
\hline \multicolumn{8}{|l|}{ Soluble-N } \\
\hline Before incubation & 103 & 9 & 122 & 14 & 121 & 28 & \\
\hline After incubation & 109 & 8 & 341 & 38 & 277 & 45 & $\mathrm{~B}-\mathrm{C}, \mathrm{T}^{* *}$ \\
\hline Increase & 6 & 3 & 219 & 29 & 156 & 28 & \\
\hline \multicolumn{8}{|l|}{ Ammonia-N } \\
\hline Before incubation & 39 & 5 & 40 & 4 & 37 & 3 & \\
\hline After incubation & 44 & 3 & 63 & 3 & 43 & 0 & $\mathrm{~B}-\mathrm{C}, \mathrm{T}^{* *}$ \\
\hline Increase & 5 & 3 & 23 & 1 & 6 & 2 & $\mathrm{C}-\mathrm{T}^{* *}$ \\
\hline \multicolumn{8}{|l|}{$\mathrm{pH}$} \\
\hline Before incubation & 6.80 & 0.00 & 6.80 & 0.00 & 6.80 & 0.00 & \\
\hline After incubation & 6.31 & 0.01 & 6.30 & 0.02 & 5.88 & 0.09 & $\mathrm{C}-\mathrm{T}^{* *}$ \\
\hline
\end{tabular}

b): standard error.

B-C, $T^{* *}$ : Differences in nitrogen increase between blank and control or test are significant at the $1 \%$ level.

$\mathrm{C}-\mathrm{T}^{* *} \quad$ : Difference in nitrogen increase or $\mathrm{pH}$ values after incubation between control and test is significant at the $1 \%$ level.

Table 4. Effect of fructose on amino-N, ammonia-N and $\mathrm{pH}$

\begin{tabular}{|c|c|c|c|c|c|c|c|}
\hline \multirow[b]{3}{*}{ Ammonia- $\mathrm{N}$} & \multicolumn{2}{|c|}{ Blank (B) } & \multicolumn{2}{|c|}{ Control (C) } & \multicolumn{2}{|c|}{ Test $(\mathbf{T})$} & \\
\hline & \multicolumn{6}{|c|}{$(\mathrm{N} \mu \mathrm{g} / \mathrm{m} l$ of reaction mixture $)$} & \\
\hline & & & & & & & \\
\hline Before incubation & $70 \pm$ & $4 \mathrm{~b}$ & $75=$ & $4 \mathrm{~b}$ & $74=$ & $4 \mathrm{~b}$ & \\
\hline After incubation & 91 & 7 & 156 & 9 & 105 & 5 & $\mathrm{~B}-\mathrm{C}, \mathrm{T}^{* *}$ \\
\hline Increase & 21 & 3 & 81 & 6 & 31 & 2 & $\mathrm{C}-\mathrm{T}^{* * *}$ \\
\hline \multicolumn{8}{|l|}{ Amino-N } \\
\hline Before incubation & 0 & 0 & 0 & 0 & 0 & 0 & \\
\hline After incubation & 0 & 0 & 36 & 7 & 43 & 5 & \\
\hline Increase & 0 & 0 & 36 & 7 & 43 & 5 & $\mathrm{~B}-\mathrm{C}, \mathrm{T}^{* *}$ \\
\hline \multicolumn{8}{|l|}{$\mathrm{pH}$} \\
\hline Before incubation & 6.80 & 0.00 & 6.80 & 0.00 & 6.80 & 0.00 & \\
\hline After incubation & 6.36 & 0.05 & 6.33 & 0.05 & 5.61 & 0.15 & $\mathrm{C}-\mathrm{T}^{* * *}$ \\
\hline
\end{tabular}

b): standard error.

B-C, T**, C-T**: See table 3 ! 


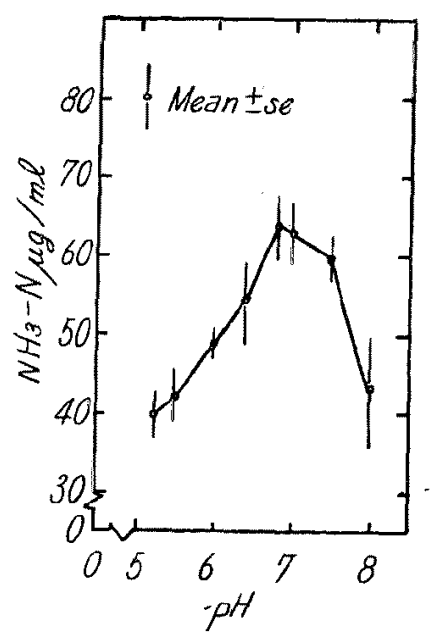

Fig. 1. Effect of $\mathrm{pH}$ on the ammonia-N concentration

\section{Discussion}

By addition of carbohydrates there is considerable decrease in ammonia- $\mathrm{N}$ concentration. MCDONaLD ${ }^{15}$ reported that when starch alone was added to the rumen of sheep during the late post-feeding stage there was a steady decline in the concentration of ammonia. ANNIson ${ }^{2)}$ showed that the rates of disappearance of ammonia and amino-acids from the rumen, after feeding casein or casein hydrolysate were increased by the additional presence of carbohydrate supplements (starch and sucrose). EL-SHazL $Y^{(6)}$ demonstrated that the addition of starch to the bean diet distinctly depressed ammonia production. LEWIS and MCDONALD ${ }^{13)}$ investigated effect of added carbohydrate on the rate of disappearance of ammonia from the rumen in detail. Levan, starch, xylan and glucose were much effective, while in the presence of cellulose there was no significant decrease in ammonia concentration until 8 hours after feeding. These results are in accord with that obtained by the author's in vitro experiments concerning the decrease in ammonia- $\mathrm{N}$ concentration.

When fructose was added to the medium, significant increase in microbial nitrogen was accompanied with decrease in ammonia- $\mathrm{N}$ concentration. PEArson and SMiTH ${ }^{18 i}$ showed that the degree of protein synthesis was increased when starch was also included in the diet. The similar results were obtained by many workers in the studies on urea utilization both in vitro and in vivo ${ }^{8,4,16)}$. Phillipson et al. ${ }^{19}$, demonstrated that number of micro-organisim increased by addition of starch. Furthermore, they ${ }^{20)}$ postulated that starch fermenting bacteria might possess the property of using ammonia nitrogen for growth.

By addition of fructose there was a fall in $\mathrm{pH}$ value and in ammonia- $\mathrm{N}$ concentration. REIS and REID ${ }^{21>}$ found that low $\mathrm{pH}$ and increased conversion of ammonia into bacterial protein occurred in vitro systems as the result of the addition of glucose. Minato et al. ${ }^{17}$ reported the fall in $\mathrm{pH}$ by the addition of starch. ELSDEN ${ }^{n}$ demonstrated that when glucose was fermented by rumen organisns, substantial amounts of volatile fatty acids (VFAs) identified as acetic, propionic, and butyric acids were formed. Using washed suspension technique, DoETsCH et al. ${ }^{5)}$ studied the action of rumen bacteria on maltose, glucose, and xylose. Acetic, 


\section{Protein Digestion in Ruminants V}

propionic and unidentified higher acids were formed. HEALD and OXFORD ${ }^{8)}$ showed that carbohydrate was fermented by rumen protozoa to VFAs, carbon dioxide and hydrogen. KumEno and KANDATSU ${ }^{12)}$ found that when starch was added to the rumen, there was an increase in VFAs concentration. The decline in $\mathrm{pH}$ value, therefore, might occur as the result of carbohydrate fermentation, namely by the production of VFAs.

From the above discussion, the effect of carbohydrate may be concluded as follows: Addition of carbohydrate stimulates the uptake of ammonia by rumen organisms and increases the microbial protein synthesis. Added carbohydrate is fermented to VFAs, so that the $\mathrm{pH}$ value of the medium goes down. The fall in $\mathrm{pH}$ value depresses the ammonia production from casein. From these results, the low ammonia concentration is observed.

In this experiment, penicillin had little effect for wide range of international unit (IU) on the ammonia concentration. Tetracycline and streptomycin decreased ammonia- $\mathrm{N}$ concentration and kanamycin had opposite effect. LEWIs and EMERY ${ }^{14}$ showed that three IU of penicilline G per milliliter of reaction mixture consisting of washed rumen bacteria had no effect on amino acid dissimilation, whereas a penicillin concentration of 30 IU per milliliter markedly inhibited amino acid dissimilation. PHILlipson et al. ${ }^{20)}$ reported that in very low concentrations $(0.1 \mu \mathrm{g} / \mathrm{m} l)$, penicillin and chlortetracycline caused a greater decrease in the cencentration of ammonia nitrogen. KLOPFENSTEIN et al. ${ }^{111}$ found that addition of $20 \mathrm{mg}$ of aureomycin increased protozoal concentration in vivo. The effect of antibiotics on the rumen micro-organisms is very complicated and should be investigated in detail in future.

\section{Summary}

1) The effect of carbohydrate and antibiotics on the ammonia- $N$ concentration was studied in vitro on the rumen liquor taken from a sheep fitted rumen fistula.

2) The marked low ammonia- $\mathrm{N}$ concentration was observed by addition of xylose, glucose, fructose, galactose, sucrose, maltose, lactose, cellobiose or raffinose.

3) The ammonia- $\mathrm{N}$ concentration also dropped by addition of mannose, dextrin, starch, inulin or xylan but the effect was rather smaller than the above group.

4) By addition of cellulose there was no significant change in ammonia- $\mathrm{N}$ concentration within 2 hours.

5) When fructose was present, significant decrease in ammonia- $N$ concentration was accompanied with significant increase in microbial nitrogen and fall in $\mathrm{pH}$ value of the medium. Amino nitrogen also increased, while the difference from control was not significant.

6) The $\mathrm{pH}$ optimum in apparent ammonia production was around $\mathrm{pH} 7.0$. And below $\mathrm{pH} 6.0$ or above 8.0 , ammonia-N concentration decreased.

7) From these results it is suggested that the addition of carbohydrate stimulates the uptake of ammonia by micro-organisms and their growth. Meanwhile, the carbohydrate is fermented to VFAs and the $\mathrm{pH}$ goes down. The low $\mathrm{pH}$ depresses the ammonia production. In these ways, the apparent ammonia- $\mathrm{N}$ concentration might be reduced.

8) Addition of penicillin had little effect on ammonia-N concentration. Tetracycline and streptomycin were effective. In the presence of kanamycin there was an increase in ammonia- $\mathrm{N}$ concentration. 


\section{HOSHINO}

\section{Acknowledgements}

The author acknowledges the assistance of Mr. H. Inoue and Mr. E. Tanabe in carring out the experiments. Acknowledgement is also due to $\mathrm{Mr}$. $\mathrm{K}$. Sarumaru for surgical work in preparation of rumen fistula.

\section{References}

1) Akabori, S. (1944) Amino Acid and Protein 1 ed. 176, Kyoritsu Shuppan, Tokyo.

2) Annison, E.F. (1956) Biochem. J., 64: 705.

3) Arias, C., W. Burroughs, P. Gerlaugh and R.M. Bethke (1951) J. Animal Sci., $10: 683$.

4) Belasco, I.J. (1956) ibid., $15: 496$.

5) Doetsch, R.N., R.Q. Robinson, R.E. Brown and J.C. Shaw (1953) J. Dairy Sci., $36: 825$.

6) El-ShazLy, K. (1958) J. Agric. Sci., $51: 149$.

7) ELSDEN, S.R. (1945) J. Exp. Biol., $22: 51$.

8) Heald, P.J. and A.E. Oxford (1953) Biochem. J., $53: 506$.

9) Hoshino, S., (1965) Jap. J. Zootech. Sci., in press.

10) Kandatsu, M. and N. Takahashi (1963) ibid., $34: 148$.

11) Klopfenstein, T.J., D.B. Purser and W.J. Tyznik (1964) J. Animal Sci., $23: 490$.

12) Kumeno, F. and M. Kandatsu (1959) J. Agric. Chem. Soc. Jap., $33: 740$.

13) LeWis, D. and I.W. McDonald (1958) J. Agric. Sci., $51: 108$.

14) LeWis, T.R. and R.S. EMRRY (1962) J. Dairy Sci., $45: 765$.

15) McDonald, I.W. (1952) Biochem. J., $51: 86$.

16) Milis, R.C., C.C. Lardinois, I.W. Rupel and E.B. Hart (1944) J. Dairy Sci., $27: 571$.

17) Minato, H., A. Endo, J. Koriyama and T. Uemura (1962) J. Agric. Chem. Soc. Jap., $36: 106$.

18) Pearson, R.M. and J.A.B. Smith (1943) Biochem. J., $37: 142$.

19) Phillipson, A.T.; M.J. Dobson and T.H. Blackburn (1959) Nature, 183: 402.

20) Phillipson, A.T., M.J. Dobson, T.H. Blackburn and M. Brown (1962) British J. Nutr., $16: 151$.

21) ReIs, P.J. and R.L. ReId (1959) Australian J. Agric. Res., 10: 71.

22) SNEDECOR, G.W. (1956) Statistical Method 5 ed. 80, 267. Iwanami Shoten, Tokyo.

23) Van Slyke-Cullen (1914) J. Biol. Chem., $19: 141$. 


\title{
反鴷動物の蛋白質消化飞関する研究
}

V. アンモニア浱度に及汸す炭水化物と抗生物質の影響

\author{
星 野 貞 夫 \\ (三重大学農学部)
}

(1965. 2. 16 受付)

1. 第一胃にフィスチュラを装着した緬羊から採取し たルーメンジュースについて in vitro でフンモニフ濃 度に及ぼす炭水化物と抗生物質の影響落研究した。

2. キシロース, グルコース, フラクトース,ガラク トース, 庶糖, 麦芽糖, 乳糖, セロビオース, ラフイ， 一スの添加でフンモニフ濃度は著しく減少を示した。

3. マンノース, デキストリン, デンプン, イヌリ ン,キシランの添加でもフンモニて浱度の減少が観察さ れたが，前記の炭水化物を添加した時より効果は小さか つた.

4. セルロースの添加には 2 時間以内に注アンモニフ 濃度は殆ど変化を示さなかつた。

5. フラクトースの添加時には有意なアンモニア濃度 の減少が有意な微生物態窒素の増加と培養液の $\mathrm{pH}$ の低 下と同時に観察された。フミノ態窒素の堌加もみられる
が有意差はなかつた。

6. 見かけのフンモ二フ生産の至適 $\mathrm{pH}$ は 7.0 周辺に あり，pH 6.0 以下，又は pH 8.0 以上ではフンモ二フ 濃度は低かった。

7. 以上の結果加ら第一胃汁によるカゼインの発醉の 際炭水化物を添加すると微生物によるフンモ二フの取込 み究刺激し，更にその成長を促進する，他方，添加さ れた炭水化物洝揮発性脂肪酸に発醉されるので培養液の $\mathrm{pH}$ は低下する。 $\mathrm{pH}$ の低下はアンモニフの生産を抑制 する.こうして，炭水化物の添加の際にフンモ二フ濃度 の低下が見られるものと推論される。

8. ペニシリンの添加はフンモニフ濃度に殆じ影響し なかつた.テトラサイタリン及びストレプトマイシンで は効果がみられた. カナマイシンの添加で㤝アンモニて 浱度の增加が観察された。 